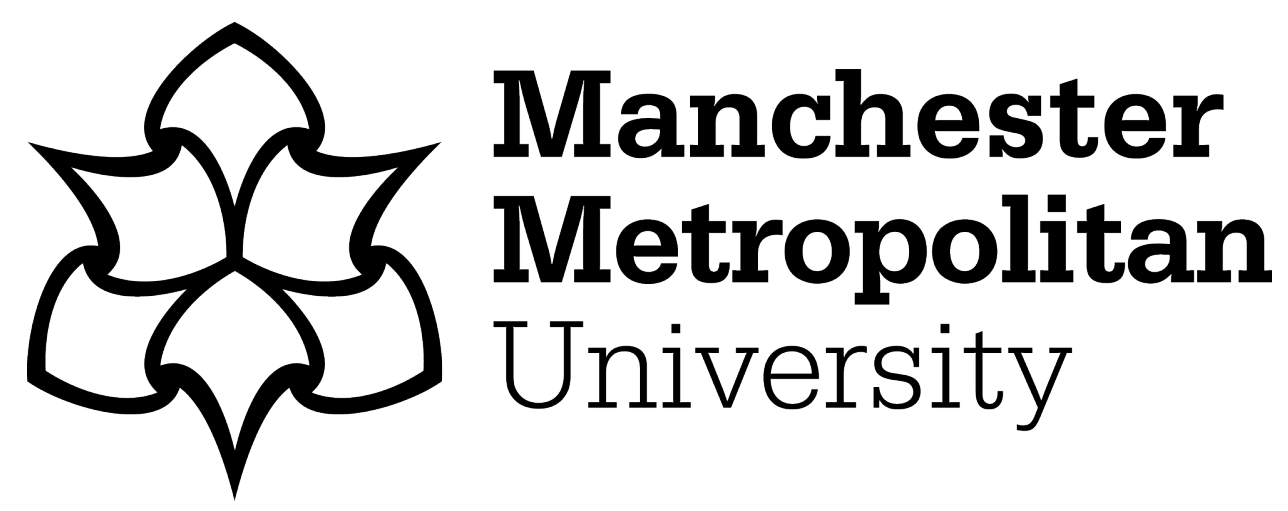

Haber, HL, Kim, P, Chmely, SC, Lloyd, J, Regmi, YN ORCID logoORCID: https://orcid.org/0000-0001-6588-7683, Abdoulmoumine, N and Labbé, N (2017) Environmentally Friendly Process for Recovery of Wood Preservative from Used Copper Naphthenate-Treated Railroad Ties. ACS Sustainable Chemistry and Engineering, 5 (11). pp. 10806-10814. ISSN 2168-0485

Downloaded from: https://e-space.mmu.ac.uk/624774/

Version: Accepted Version

Publisher: American Chemical Society (ACS)

DOI: https://doi.org/10.1021/acssuschemeng.7b02760

Please cite the published version 


\title{
Environmentally Friendly Process for Recovery of Wood Preservative from Used Copper Naphthenate-Treated Railroad Ties
}

\author{
Holly L. Haber, ${ }^{\dagger}$, Pyoungchung Kim, $^{\dagger \oplus}$ Stephen C. Chmely, ${ }^{\dagger}{ }^{\dagger}$ Jeff Lloyd, ${ }^{\S}$ Yagya N. Regmi, ${ }^{\dagger} \odot$ \\ Nourredine Abdoulmoumine, ${ }^{*}$ and Nicole Labbé ${ }^{*} \dagger \oplus$ \\ $\dagger$ Center for Renewable Carbon, The University of Tennessee, 2506 Jacob Drive, Knoxville, Tennessee 37996, United States \\ ${ }^{\ddagger}$ Biosystems Engineering \& Soil Science, The University of Tennessee, 2506 E.J. Chapman Drive, Knoxville, Tennessee 37996, United \\ States

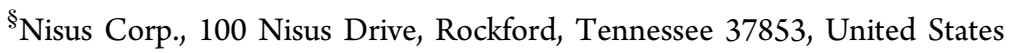

\begin{abstract}
Removal of copper naphthenate $(\mathrm{CN})$ from used wooden railroad ties was investigated to improve the commercial viability of this biomass as a fuel source and avoid alternative disposal methods such as landfilling. Bench-scale thermal desorption of organic preservative components from $\mathrm{CN}$-impregnated ties was followed by extraction of the copper fraction with ethylenediaminetetraacetic acid, 1hydroxy ethylidene-1,1-diphosphonic acid, or 2,6-pyridine dicarboxylic acid (PDA). Naphthenic acid (NA) and carrier oil were recovered at desorption temperatures between 225 and $300{ }^{\circ} \mathrm{C}$ and could potentially be recycled to treat new ties. The thermal treatment also mimicked torrefaction, improving the biomass properties for use as a thermochemical conversion feedstock. Chelation with PDA, a biodegradable chelating agent, after desorption had the highest extraction efficiency of copper and other naturally present inorganics, extracting $100 \%$ of the copper from both the raw and $225{ }^{\circ} \mathrm{C}$-treated samples. Optimized desorbed material showed a $64 \%$ decrease in

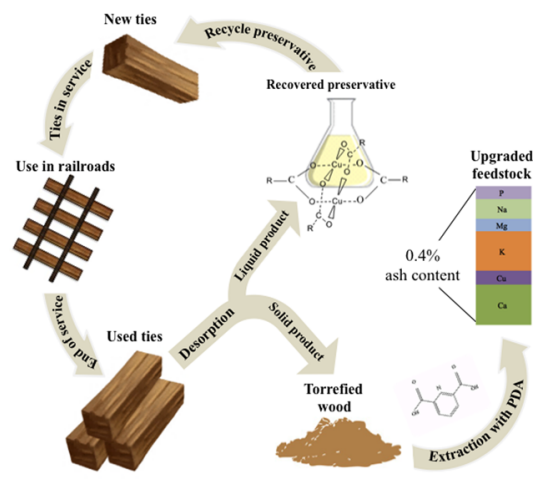
ash content when extracted with PDA; however, extraction efficiency decreased as desorption temperature increased, indicating that thermal treatment caused the inorganics to be less extractable. We concluded that the optimum desorption conditions were between 250 and $275{ }^{\circ} \mathrm{C}$ for 45 min followed by extraction with PDA when considering both NA removal and inorganic extraction efficiency.
\end{abstract}

KEYWORDS: 1-Hydroxy ethylidene-1,1-diphosphonic acid (HEDP), 2,6-Pyridine dicarboxylic acid (PDA), Chelation, Copper naphthenate (CN), Ethylenediaminetetraacetic acid (EDTA), Preservative, Railway sleeper, Thermal desorption, Used ties

\section{INTRODUCTION}

Copper naphthenate $(\mathrm{CN})$ is an oil-borne preservative composed of naphthenic acids (NA) and salts of copper ions effective against fungi, bacteria, and molds. ${ }^{1}$ Approximately 267 million cubic feet of lumber are treated with oil-borne preservatives, including $\mathrm{CN}$ and pentachlorophenol (both diluted in carrier oil), per year. ${ }^{2}$ High-pressure treatment is used to apply $\mathrm{CN}$ into wooden railroad ties before field installation to slow biodeterioration. This treatment results in a retention of $0.06 \mathrm{pcf}$ as copper in the wood and an assay zone of one inch from the edge of the tie. ${ }^{3}$ After being removed from railroads, the majority of preservative-treated railroad ties become a fuel source in large industrial boilers permitted for burning biomass. Changes to boiler emissions regulations such as those dictated in the EPA's Non Hazardous Secondary Materials Rule, for example, ${ }^{4}$ combined with the low current price of natural gas have resulted in a larger amount of ties being discarded in landfills as an alternative. The use of fossil fuels and other nonwood alternatives has also increased in response, further contributing to the release of greenhouse gases already augmented by the decomposition of CN-treated ties in landfills. ${ }^{5}$

Thermal desorption has been shown to be an effective treatment method for recovering the preservative creosote from used railroad ties. ${ }^{6}$ Advantages of thermal desorption over the use of an organic solvent include a lower cost, no preservative dilution, and upgrading of the quality of the ties for further thermochemical conversion processes with improved properties similar to those of torrefied biomass. ${ }^{7-9}$ Torrefaction, typically carried out between 200 and $300{ }^{\circ} \mathrm{C}$, causes a substantial rise in the calorific value and carbon content of woody biomass in particular. $^{10}$ The combined reduction in moisture and volatilization of oxygen and hydrogen-rich compounds during torrefaction results in a feedstock with a higher energy density, lower specific grinding energy, better storage stability, and smaller average particle size than untreated biomass, all of

Received: August 11, 2017

Revised: September 29, 2017

Published: October 10, 2017 
which are beneficial for thermochemical conversion processes. $^{11}$

Although thermal treatment is an effective method for recovery of the organic fraction of wood preservatives, $\mathrm{CN}$ contains an additional inorganic fraction not found in creosote that remains in the biomass after desorption. Many inorganics such as alkali and alkaline earth metals in particular have been reported to possess undesired catalytic effects on thermochemical conversion processes such as pyrolysis. ${ }^{12-14}$ The presence of copper and these other metals leads to a decrease in yield and intensification of physical and chemical issues such as slagging, clogging, and degradation of reactor walls from corrosion and deactivation of catalysts. ${ }^{14}$ Chelating agents are often used as an extraction method for the removal of inorganics from biomass, including those that have these detrimental effects. One of the most common of these chelating agents is ethylenediaminetetraacetic acid (EDTA), which has shown high efficiency in heavy metal removal from preservative-treated wood. ${ }^{15-17}$ This chelating agent, however, is not biodegradable and is hazardous to the environment, ${ }^{16,18}$ causing its use to be restricted or banned for various applications in European countries. ${ }^{19}$ Alternatives to EDTA such as 1-hydroxy ethylidene-1,1-diphosphonic acid (HEDP) and 2,6-pyridine dicarboxylic acid (PDA) are gaining popularity for inorganic removal because of their extraction efficiency comparable to that of traditional chelating agents as well as their biodegradability. ${ }^{20}$ HEDP belongs to the organophosphate group of chelating agents, while PDA is a naturally occurring compound in bacterial spores. ${ }^{21}$ HEDP chelates with copper in a 1:1 ratio such as EDTA, ${ }^{22}$ whereas PDA contains 3 possible coordination sites with metal ions and typically chelates in a 2:1 (chelator:metal) ratio. ${ }^{20}$

However, the thermal treatment of $\mathrm{CN}$-impregnated wood may have an effect on the copper and naturally present inorganics found in the ties, in addition to the ease of their extraction with these chelating agents. ${ }^{23,24}$ For example, a study by Barnes et al. ${ }^{23}$ found that steam treatment of $\mathrm{CN}$-treated wood poles led to the formation of inert $\mathrm{Cu}_{2} \mathrm{O}$. Heat treatment in the presence of moisture can also cause the surface of the wood to become hydrophobic, which reduces the wood's uptake of water and limits the movement of these inorganics within the wood structure. ${ }^{11,23,25,26}$ A higher hydrophobicity would also restrict water diffusion across the wood cell wall.

In this study, we investigated the recovery of $\mathrm{CN}$ components from used railroad ties with thermal treatment between 200 and $300{ }^{\circ} \mathrm{C}$ and RT from 30 to $60 \mathrm{~min}$ followed by extraction with $1 \%$ solutions of EDTA, HEDP, and PDA. We propose that this process will improve the commercial viability of using spent ties as fuel if they can be recycled to capture the value of the copper naphthenate and oil and consequently be used to produce a high-quality feedstock for thermochemical processes such as pyrolysis.

\section{EXPERIMENTAL SECTION}

Material. Copper naphthenate impregnated railroad ties composed of several different hardwood species, including oak, hickory, and gum, were provided prechipped by Nisus Corporation (Rockford, TN) in large 55 gallon plastic drums. Six whole ties were run through a commercial chipper, and then a subsample was further processed using a knife mill to produce the material that was ultimately provided. The volume received was equal to that of approximately two ties but contained mixed material from the original six. This was done to ensure the sample was representative with regard to both typical retention and commercial species mix. The chips were then ground using a Wiley Mill to less than $2 \mathrm{~mm}$ size prior to all analysis and stored in an airtight container.

Characterization of the Used Tie Material. Proximate analysis of the untreated ties (as received) sample included determination of moisture content, ash content, and the percent volatile matter of the CN-treated railroad ties using American Society for Testing and Materials (ASTM) standard method D1762: Standard Test Method for Chemical Analysis of Wood Charcoal. To summarize, porcelain crucibles were heated in a furnace and then placed in a desiccator until completely cooled. Approximately $1 \mathrm{~g}$ of the ground ties was then added to each crucible and placed into an oven at $105^{\circ} \mathrm{C}$ overnight to remove water. Samples were then cooled in a desiccator and weighed gravimetrically to determine moisture content. These same crucibles were then covered with a lid and placed into a furnace at $950{ }^{\circ} \mathrm{C}$ for 10 min each. They were again cooled and weighed to determine volatile matter. Finally, the uncovered crucibles were placed in a furnace at 575 ${ }^{\circ} \mathrm{C}$ overnight, cooled, and weighed to calculate ash content of the samples. All experiments were performed in triplicate.

Removal of Oil and Naphthenic Acids by Thermal Desorption. Pyrolysis-gas chromatography/mass spectrometry (PyGC/MS) was used to monitor the desorption of preservative components under different temperatures and residence times from the $\mathrm{CN}$-treated railroad material. The method was adapted from that used by Kim et al. to desorb creosote in used ties. ${ }^{6}$ This screening was done using a Frontier EGA/Py-3030 D micropyrolyzer and autosampler connected to a PerkinElmer Clarus 680 gas chromatography and Clarus SQ mass spectrometer. Approximately $300 \pm 30 \mu \mathrm{g}$ of the raw sample were put into each sample pan that was placed into an autosampler, which then fed into the pyrolysis furnace. The pyrolysis furnace was maintained at $200,225,250,275$, or $300{ }^{\circ} \mathrm{C}$ for 10,20 , or $30 \mathrm{~min}$. When each residence time ended, helium $(1 \mathrm{~mL} /$ $\min )$ carried the resulting vapor into the GC-injection port $\left(270{ }^{\circ} \mathrm{C}\right)$ at a split ratio of $80: 1$. Once there, the following GC temperature program was started: begin at $50{ }^{\circ} \mathrm{C}$ for 4 min holding time, increase to $280{ }^{\circ} \mathrm{C}$ at $5{ }^{\circ} \mathrm{C} / \mathrm{min}$, and then hold for $5 \mathrm{~min}$ at $280{ }^{\circ} \mathrm{C}$. An Elite 1701 MS capillary column was used for vapor separation prior to MS analysis. MS analysis was conducted with a source temperature of 270 ${ }^{\circ} \mathrm{C}$ and electron ionization of $70 \mathrm{eV}$. The results were then compared with the NIST library for identification. Triplicates were collected for each Py-GC/MS experiment.

After testing with Py-GC/MS, thermal desorption of oil and NA with a bench-scale fixed bed reactor was tested to determine the scalability of this process (Figure S1). Desorption of the organic fraction of the $\mathrm{CN}$ from the railroad ties was tested at $225,250,275$, and $300{ }^{\circ} \mathrm{C}$ for 30,45 , and $60 \mathrm{~min}$ residence time under constant nitrogen flow of $2 \mathrm{~L} / \mathrm{min}$. Retention times (RT) longer than those with the Py-GC/MS were used to address the slower heat transfer through the tubular furnace of the fixed-bed reactor. Additionally, only the highest four temperatures were investigated with this reactor because very little desorbed preservative was observed at $200{ }^{\circ} \mathrm{C}$ by $\mathrm{PyGC} / \mathrm{MS}$. The fixed-bed reactor consisting of a tubular furnace was fitted with four condensers to collect the desorbed preservative. Approximately $30 \mathrm{~g}$ of $\mathrm{CN}$-treated wood (as provided) was placed inside of the furnace at each time-temperature combination. Nitrogen gas carried the volatilized compounds from the sample to the condensers where they were then collected using $250 \mathrm{~mL}$ of acetone solvent. All four condensers were filled with liquid nitrogen during the full duration of each run to condense the vapor.

Analysis of Recovered Naphthenic Acids and Carrier Oil. The liquid fraction from the walls of the condensers after desorption at each condition was recovered after the complete removal of the acetone using a rotary evaporator. Each recovered liquid was combined with approximately $1.7 \mu \mathrm{L}$ of cyclopentylacetic acid and $1300 \mu \mathrm{L}$ of toluene to form solutions. A $1 \mu \mathrm{L}$ aliquot of each solution was then directly injected into the GC/MS for identification and quantification of the recovered preservative components desorbed from the ties. A PerkinElmer Clarus 680 gas chromatograph coupled with a Clarus SQ mass spectrometer was used for this analysis at a split ratio of 50:1 with the GC-injection port maintained at $270{ }^{\circ} \mathrm{C}$. The GC temperature program started at $50{ }^{\circ} \mathrm{C}$, was held at that temperature 


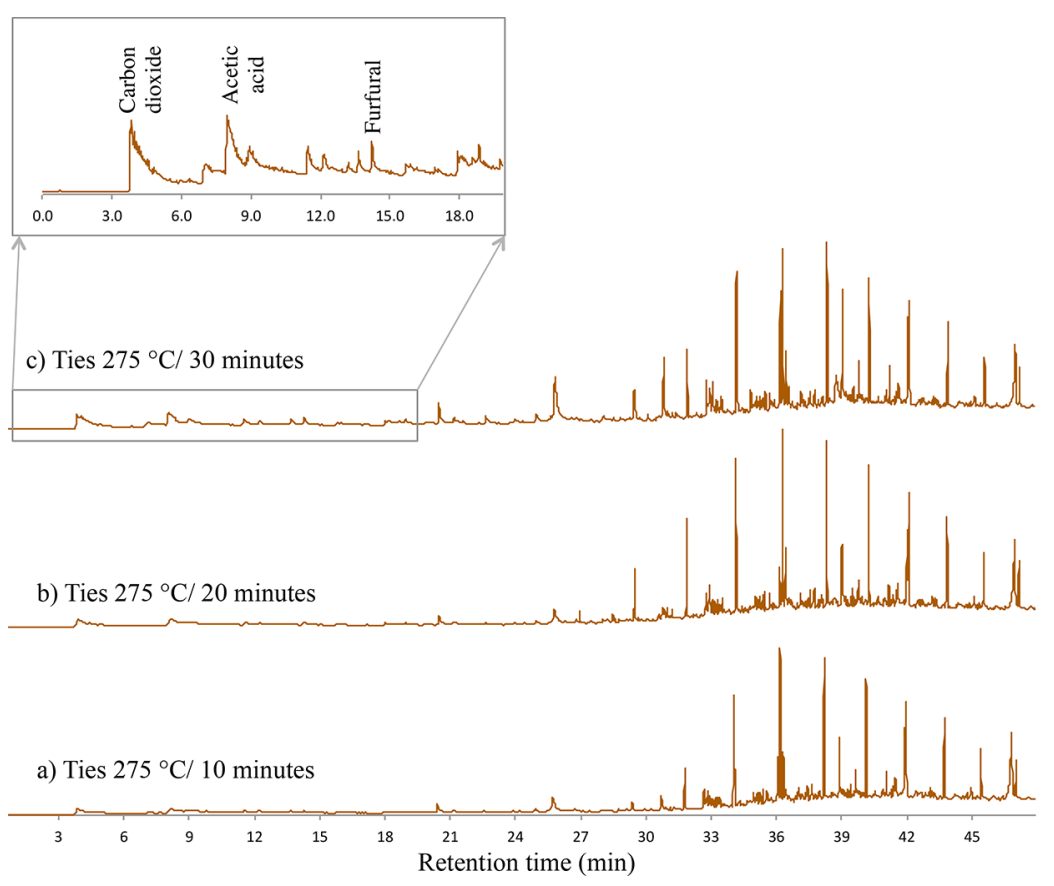

Figure 1. Thermal desorption of copper naphthenate-treated railroad ties by Py-GC/MS at $275{ }^{\circ} \mathrm{C}$ for (a) 10, (b) 20, and (c) 30 min.

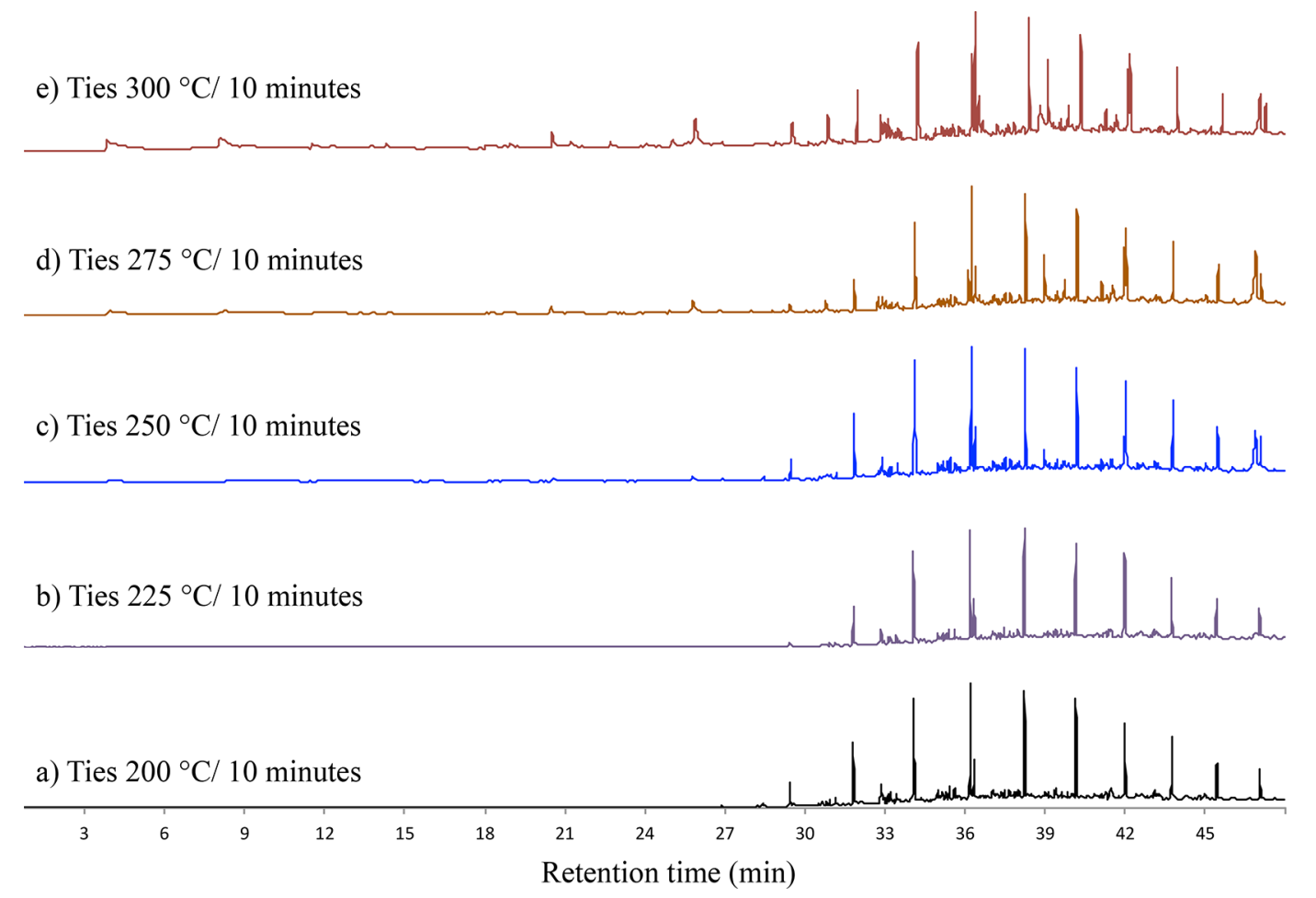

Figure 2. Thermal desorption of copper naphthenate-treated railroad ties by Py-GC/MS for 10 min at (a) 200, (b) 225, (c) 250, (d) 275, and (e) $300{ }^{\circ} \mathrm{C}$.

for 4 min, then increased to $280{ }^{\circ} \mathrm{C}$ at $5{ }^{\circ} \mathrm{C} / \mathrm{min}$, and finally held for $10 \mathrm{~min}$ at $280^{\circ} \mathrm{C}$. An Elite $1701 \mathrm{MS}$ capillary column was again used for volatilized vapor separation prior to analysis using MS and comparison with the NIST library. MS analysis was conducted with a source temperature of $270{ }^{\circ} \mathrm{C}$ and electron ionization of $70 \mathrm{eV}$. Triplicates were collected for each GC/MS experiment.

Analysis of Thermally Treated Solid Fraction. The particle size distribution of each sample after being thermally treated was determined using a set of sieves with multiple particle sizes $(2.83$ $\mathrm{mm}, 2.38 \mathrm{~mm}, 2 \mathrm{~mm}, 0.4 \mathrm{~mm},<4 \mathrm{~mm}$ ) and a mechanical shaker. The portion of sample remaining in each sieve after shaking for five min at $500 \mathrm{rpm}$ was determined gravimetrically and compared to that of the untreated sample. Proximate analysis of the solid wood samples after thermal desorption was also conducted using the same methods employed to characterize the untreated sample in Characterization of the Used Tie Material, and ultimate analysis using a 2400 Series II CHN Analyzer (PerkinElmer) was conducted to measure the percentage of carbon, hydrogen, oxygen, and nitrogen within the thermally desorbed samples. Additionally, scanning electron microscope images were collected on a Zeiss Dual Beam FIB/SEM 
instrument. The samples were deposited on double sided carbon tape and coated with gold prior to characterization.

Extraction of Inorganics with Chelating Agents. Copper and other biomass inorganics that negatively affect pyrolysis were extracted from the thermally desorbed ties using a 1\% solution of EDTA $(\mathrm{pH}$ 5.5), HEDP (CAS 2809-21-4) (pH 1.5), or PDA (CAS 499-83-2) $(\mathrm{pH} 4)$. The thermally desorbed ties were also extracted with deionized water as a control. The $\mathrm{pH}$ of chelating agents affects their extraction efficiency, so this parameter was adjusted to values shown to have high extraction efficiency of copper in the literature. $24,27,28$ Ammonium hydroxide was used for $\mathrm{pH}$ adjustment of the solutions so as not to introduce any new inorganics into the systems. A traditional batch extraction method was used where the reaction temperature was held constant at $75{ }^{\circ} \mathrm{C}$ during each $3 \mathrm{~h}$ extraction with constant stirring at $150 \mathrm{rpm}$. A solution:liquid ratio of 15:1 was used for each test. ${ }^{18,19}$ After each extraction, the solid was separated from the liquid using a Whatman no. 2 filter. The liquid was then centrifuged for 20 min at $1000 \mathrm{rpm}$ to further remove any small solid particles from the liquid samples.

Inductively coupled plasma-optical emission spectrometry (ICPOES) (PerkinElmer Optima 7300 Dual View, Shelton, CT) was conducted after chelation to determine the inorganic composition of the liquid extracted from the ties. Reagent grade nitric acid (67-70\%) $(1 \mathrm{~mL})$ was added to $15 \mathrm{~mL}$ of each liquid sample for acidification of the solutions, which were then passed through $0.2 \mu \mathrm{L}$ filters and analyzed using ICP-OES analysis to determine the composition of inorganics leached from each sample. The determined phosphorus concentration extracted from each sample chelated with HEDP was corrected based on the molecular weight of the chelating agent.

\section{RESULTS AND DISCUSSION}

Removal of Oil and Naphthenic Acids by Thermal Desorption. Copper naphthenate is composed of NA, copper ions, and carrier oil. ${ }^{29}$ Because the inorganic fraction of the preservative does not volatilize at the selected temperature range, only the oil and NA (organic fraction) can be removed by thermal desorption. Py-GC/MS was used to monitor the desorption of these NA and carrier oil from the used railroad ties at $200,225,250,275$, or $300{ }^{\circ} \mathrm{C}$ for varied residence times to determine the optimal thermal desorption conditions. Several hundred different compounds that vary based on the source make up naphthenic acid, so quantifying the amount of this component contained within the ties using Py-GC/MS is difficult. Instead of clearly defined $\mathrm{CN}$ peaks, the presence of the NA results in a bump shape along the baseline of the pyrograms (Figure S2). ${ }^{30}$ The area decreases as the preservative is removed from the wood ties. The tall clearly defined peaks that appear from a RT of about 30 to $50 \mathrm{~min}$ can be identified as tetradecane, nonadecane, and other solvent compounds.

Figure 1 shows thermal desorption of the ground ties using Py-GC/MS at a constant temperature $\left(275^{\circ} \mathrm{C}\right)$ with the RT varying from 10 to $30 \mathrm{~min}$, while Figure 2 depicts a change in desorption temperature at a constant time. Little variation in the pyrograms occurred with an increase in RT. However, a slight decrease in the NA area with an increase in temperature supports that more preservative component is desorbed at higher temperatures (Figure 2). Higher temperatures also result in the detection of larger carbon dioxide, acetic acid, furfural, and other phenolic compound peaks (Figure 1), which indicates the partial decomposition of the wood matrix. Peaks present at approximately 30.7 and $32.7 \mathrm{~min} \mathrm{RT}$ increase in height at higher temperatures due to an increase in phenolic compounds from the breakdown of lignin, thus further demonstrating this decomposition. ${ }^{6}$ This loss in carbon negatively affects the wood's yield as a potential thermochemical conversion feedstock by resulting in a smaller amount of upgraded feedstock produced as well as increases the ash content (\%) of that feedstock. Therefore, there is a trade-off between the highest removal of preservative at these higher temperatures and the degradation of the wood matrix.

Thermal desorption of NA on a larger scale using a fixed bed reactor was then conducted to assess the scalability of the process and validate the trends seen by Py-GC/MS. It was also possible to monitor mass loss at this scale (Table 1). Mass loss

Table 1. Mass Loss of Copper Naphthenate-Treated Railroad Ties from Bench-Scale Thermal Desorption under Varying Retention Time and Temperature

\begin{tabular}{ccc}
$\begin{array}{c}\text { desorption temperature } \\
\left({ }^{\circ} \mathrm{C}\right)\end{array}$ & $\begin{array}{c}\text { desorption time } \\
(\mathrm{min})\end{array}$ & $\begin{array}{c}\text { average mass loss } \\
(\%)\end{array}$ \\
\hline 225 & 30 & $17.2(0.3)$ \\
& 45 & $20.4(0.5)$ \\
250 & 60 & $20.9(1.9)$ \\
& 30 & $23.4(0.2)$ \\
275 & 45 & $27.3(0.3)$ \\
& 60 & $28.9(0.6)$ \\
& 30 & $32.9(0.5)$ \\
300 & 45 & $37.4(1.1)$ \\
& 60 & $38.6(0.4)$ \\
& 30 & $45.0(0.4)$ \\
& 45 & $49.2(2.8)$ \\
& 60 & $54.7(1.2)$ \\
\end{tabular}

${ }^{a}$ Average (standard deviation) of triplicates.

with the lowest treatment severity (desorption at $225^{\circ} \mathrm{C}$ for 30 $\min$ ) is $17.2 \%$ and reaches $54.7 \%$ at the highest. A larger mass loss is expected with a greater decomposition of the wood matrix. In all cases, there is a significant increase between the 30 and 45 min RT trials but a much smaller difference between the 45 and $60 \mathrm{~min}$ at each temperature (Table 1). For example, a difference in mass loss of about $4 \%$ occurred at $275{ }^{\circ} \mathrm{C}$ when the residence time was lengthened from 30 to $45 \mathrm{~min}$; however, a change of only about $1 \%$ occurred when the residence time was increased from 45 to $60 \mathrm{~min}$. Thus, for optimal NA desorption, a RT of 45 min should not be exceeded at any treatment temperature.

In addition to a higher removal of NA and carrier oil solvent from the ties, these mass losses can be attributed to the removal of moisture and the loss of carbon from the breakdown of the wood matrix, in particular hemicellulose. ${ }^{11}$ Higher amounts of carbon dioxide and water are released at more severe torrefaction conditions. A greater decomposition of the wood constituents occurs as severity of thermal treatment conditions increase, as seen in the Py/GC-MS data in Figure 1. Thus, severity should be minimized when generating a feedstock for subsequent thermochemical conversion processes. The trends seen with thermal desorption using the bench-scale reactor mirror those observed by $\mathrm{Py}-\mathrm{GC} / \mathrm{MS}$, which supports scalability of the desorption process.

Scanning electron microscopy (SEM) was used to verify that a higher breakdown of the wood structure occurred as benchscale thermal desorption temperature rose. Intervessel pitting and scalariform perforations, typical of hardwoods, are visible in the vessels of the thermally desorbed samples in SEM images at $250{ }^{\circ} \mathrm{C}$ (Figure $3 \mathrm{c}$ ) and $275{ }^{\circ} \mathrm{C}$ (Figure $3 \mathrm{~d}$ ). ${ }^{31}$ Degradation of these tissues becomes larger and more prevalent as thermal desorption temperature increases, with almost complete morphological degradation occurring at $300{ }^{\circ} \mathrm{C}$ (Figure 


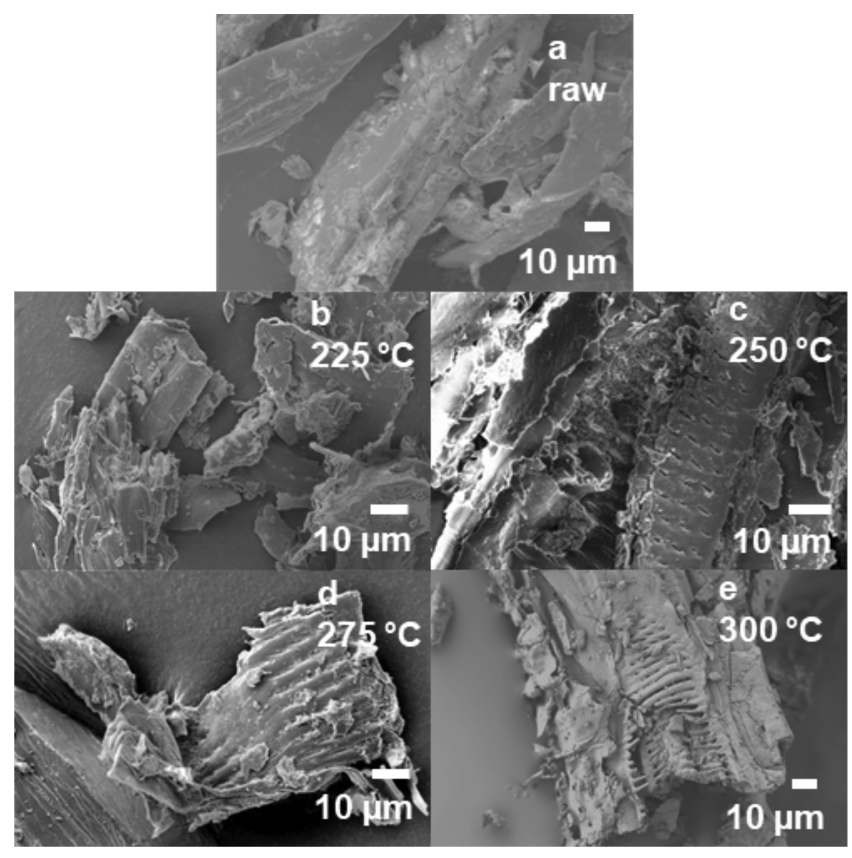

Figure 3. Scanning electron micrographs of wood ties thermally desorbed with a bench-scale fixed bed reactor for $45 \mathrm{~min}$ at (a) raw sample (no thermal treatment), (b) 225, (c) 250, (d) 275, and (e) 300 ${ }^{\circ} \mathrm{C}$.

3e). ${ }^{32,33}$ This decomposition can be attributed to the breakdown of biomass components such as lignin (275-500 $\left.{ }^{\circ} \mathrm{C}\right)$, cellulose, and hemicellulose $\left(150-350{ }^{\circ} \mathrm{C}\right) .{ }^{32,34}$

Properties of Recovered Naphthenic Acid and Carrier Oil. After each thermal desorption using the bench-scale reactor, the condensed liquid was recovered from the reactor using acetone. This liquid fraction was composed of two distinct phases, a water fraction and an organic fraction, which were separated and weighed for yield quantification (Table 2)

Table 2. Yield of Organic Liquid Fraction from Bench-Scale Thermal Desorption of Ties

$\begin{array}{ccc}\begin{array}{c}\text { thermal desorption } \\ \text { temperature }\left({ }^{\circ} \mathrm{C}\right)\end{array} & \begin{array}{c}\text { retention time } \\ (\mathrm{min})\end{array} & \begin{array}{c}\text { weight of extracted organic } \\ \text { phase }(\mathrm{g})^{a}\end{array} \\ 225 & 30 & 0.11 \\ 45 & 0.11 \\ 60 & 0.12 \\ 250 & 30 & 0.15 \\ & 45 & 0.19 \\ & 60 & 0.19 \\ 275 & 30 & 0.19 \\ & 45 & 0.21 \\ & 60 & 0.21 \\ 300 & 30 & 0.19 \\ & 45 & 0.19 \\ & 60 & 0.28\end{array}$

${ }^{a}$ Per $30 \mathrm{~g}$ of raw biomass treated.

prior to analysis. The amount recovered increases with thermal desorption time and temperature (Table 2). Approximately $0.11 \mathrm{~g}$ of total liquid was recovered with a $30 \mathrm{~min}$ thermal treatment at $225{ }^{\circ} \mathrm{C}$, while $0.28 \mathrm{~g}$ was removed using the most severe treatment conditions of $300{ }^{\circ} \mathrm{C}$ and $60 \mathrm{~min}$. Because the organic fraction of the recovered liquid includes mainly preservative components and wood decomposition byproducts, this increase in yield suggests both a larger amount of naphthenic acid and carrier oil being desorbed as well as a larger decomposition of the wood matrix.

Aliquots from the recovered organic fraction were combined in solution with toluene and cyclopentylacetic acid before being directly injected into a GC/MS for identification and quantification of the major components. The profile of the liquid phase is very similar to the profile obtained from the desorbed vapor by Py-GC/MS. The major peaks are identified as compounds derived from the carrier oil solvent that was used to help CN penetrate the wood ties' cell walls. The bump shape below the solvent peaks and above the baseline in each chromatogram is caused by the presence of NA (Figure S2). ${ }^{30}$ In regards to the solvent peaks, no differences exist between the different desorption conditions; however, the total NA area is larger with an increase in temperature (Figure 4). Due to the lower boiling point of NA $\left(130-240{ }^{\circ} \mathrm{C}\right)$ in comparison with that of the carrier oil solvent $\left(280-340^{\circ} \mathrm{C}\right)$, this component of the preservative would be expected to volatilize at the lower desorption temperatures, thus supporting the observation. ${ }^{35,36}$ The amount of NA recovered at temperatures above $250{ }^{\circ} \mathrm{C}$ drastically rises from that at less severe conditions. However, very little difference exists between the $45 \mathrm{~min}$ desorption at 275 and $300{ }^{\circ} \mathrm{C}$. This plateau suggests that NA removal is maximized between 250 and $275{ }^{\circ} \mathrm{C}$.

Properties of Solid Residual Thermally Treated Ties. The moisture content of the thermally desorbed railroad ties decreases with an increase in time as well as temperature (Table 3 ). Moisture content of the railroad ties prior to treatment is $9.6 \%$, which is reduced to $1.3 \%$ after desorption at $300{ }^{\circ} \mathrm{C}$ for $60 \mathrm{~min}$. Lower moisture content is beneficial for a pyrolysis feedstock by making the material easier to store and transport prior to conversion, in addition to producing a higher quality bio-oil. ${ }^{11}$ Therefore, thermal treatment improves the wood quality for use as a pyrolysis feedstock. Removal of hydrogen and oxygen in the form of water and other compounds results in a higher amount of fixed carbon present in the ties as desorption temperature and time increase. The same trend can be seen with the change in carbon content which augments from 51.0 to $59.3 \%$, accompanying a decrease in hydrogen and oxygen from 6.7 to $5.2 \%$ and 41.5 to $33.4 \%$, respectively. The ash content is relatively low in all conditions but slightly increases from $1.2 \%$ in the starting material to $1.9 \%$ at the highest desorption severity, thus further supporting conditions with lower severity for optimizing recovery of NA from the ties.

The percentage of smaller sized particles also increases as a result of this greater decomposition (Figure 5). The number of smaller particles present in all desorbed samples is larger than in the untreated sample. Approximately half of the particles in every desorbed sample are between a 0.4 and $2 \mathrm{~mm}$ particle size. Biomass particle size is often reduced as a result of torrefaction ${ }^{37}$ due to the wood becoming more brittle and more easily ground; therefore, this trend is expected within our selected desorption temperature range.

A reduction in particle size is also advantageous for the subsequent chelation process. ${ }^{38,39}$ Typically, higher extraction efficiencies are achieved when extracting from smaller biomass particles than from larger chunks due to an increase in specific wood surface area. ${ }^{38,39}$ Larger surface area allows the metals to become more accessible to the chelating agents. ${ }^{39}$

Extraction of Inorganics with Chelating Agents. Following thermal desorption, extraction of the inorganics within the thermally treated ties was tested using deionized 


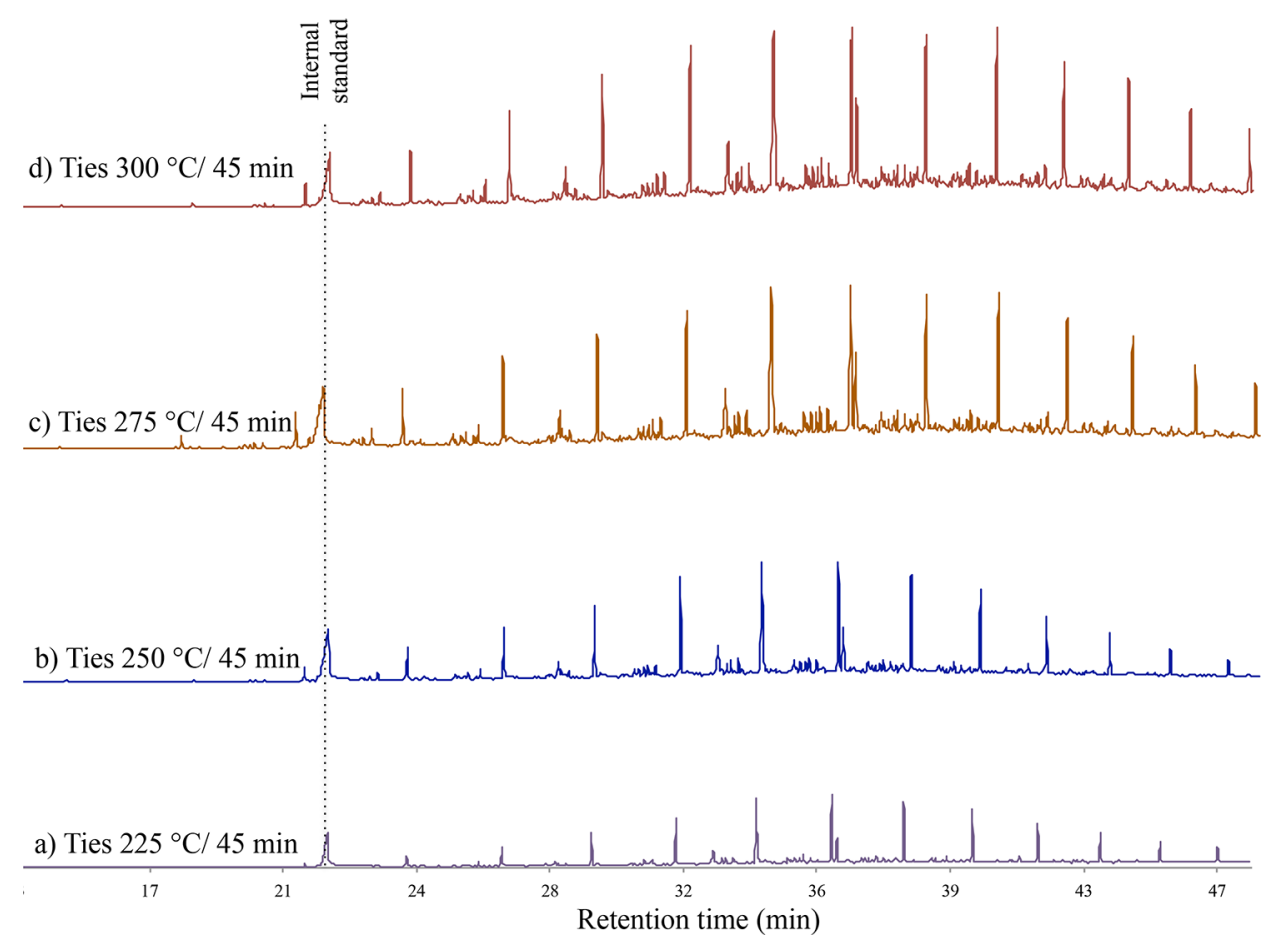

Figure 4. GC/MS of recovered liquid organic phase from bench-scale thermal desorption of railroad ties for 45 min at (a) 225, (b) 250, (c) 275, and (d) $300{ }^{\circ} \mathrm{C}$.

Table 3. Proximate and Ultimate Analysis of Used Railroad Ties Thermally Desorbed with a Fixed Bed Reactor

\begin{tabular}{|c|c|c|c|c|c|c|c|}
\hline desorption temperature $\left({ }^{\circ} \mathrm{C}\right)$ & desorption time ( $\mathrm{min}$ ) & moisture content $(\%)^{a}$ & ash content $(\%)^{a}$ & fixed carbon (\%) & $\% \mathrm{C}^{a}$ & $\% \mathrm{H}^{a}$ & $\% \mathrm{O}^{a, b}$ \\
\hline \multirow{3}{*}{225} & starting material & $9.6(0.3)$ & $1.2(0.1)$ & 4.0 & $50.5(0.2)$ & $6.7(0.3)$ & $41.5(0.3)$ \\
\hline & 30 & $4.7(0.1)$ & $1.0(0.1)$ & 12.9 & $50.9(0.2)$ & $6.2(0.1)$ & $42.2(0.3)$ \\
\hline & 45 & $4.0(0.1)$ & $1.0(0.1)$ & 13.4 & $51.0(0.4)$ & $5.8(0.1)$ & $42.9(0.5)$ \\
\hline \multirow{4}{*}{250} & 60 & $3.3(0.1)$ & $1.0(0.1)$ & 13.7 & $50.5(0.2)$ & $5.8(0.2)$ & $43.1(0.2)$ \\
\hline & 30 & $2.9(0.1)$ & $1.1(0.1)$ & 17.2 & $50.7(0.1)$ & $5.8(0.1)$ & $42.1(0.2)$ \\
\hline & 45 & $2.8(0.1)$ & $1.2(0.1)$ & 18.1 & $52.0(0.2)$ & $5.9(0.4)$ & $41.0(0.6)$ \\
\hline & 60 & $2.7(0.4)$ & $1.2(0.4)$ & 17.5 & $52.4(0.3)$ & $6.0(0.1)$ & $40.7(0.4)$ \\
\hline \multirow[t]{2}{*}{275} & 30 & $1.2(0.3)$ & $1.3(0.2)$ & 20.1 & $53.1(0.3)$ & $5.8(0.1)$ & $39.7(0.4)$ \\
\hline & 45 & $1.0(0.1)$ & $1.4(0.1)$ & 22.5 & $54.2(0.1)$ & $5.7(0.1)$ & $38.6(0.1)$ \\
\hline \multirow{4}{*}{300} & 60 & $1.0(0.4)$ & $1.4(0.2)$ & 23.7 & $54.9(0.1)$ & $5.4(0.1)$ & $38.1(0.2)$ \\
\hline & 30 & $1.7(0.2)$ & $1.4(0.2)$ & 27.2 & $56.5(0.1)$ & $5.2(0.3)$ & $36.8(0.3)$ \\
\hline & 45 & $1.2(0.3)$ & $1.6(0.1)$ & 31.7 & $57.3(1.4)$ & $5.2(0.2)$ & $35.8(1.6)$ \\
\hline & 60 & $1.3(0.7)$ & $1.9(0.3)$ & 33.4 & $59.3(0.4)$ & $5.2(0.1)$ & $33.4(0.5)$ \\
\hline
\end{tabular}

${ }^{a}$ Mean (standard error). ${ }^{b}$ Percent oxygen calculated by difference.

water and $1 \%$ solutions of three chelating agents: EDTA, HEDP, and PDA. Figure 6 demonstrates the composition of inorganics extracted from the thermally desorbed samples with the bench-scale reactor for $45 \mathrm{~min}$ at temperatures between 225 and $300{ }^{\circ} \mathrm{C}$. Overall extraction efficiency of inorganics from the thermally desorbed ties is the highest with PDA, followed by HEDP, EDTA, and then water (Figure 6). Over $90 \%$ of copper and other inorganics known for having detrimental effects on pyrolysis are extracted from the raw sample using all of the agents tested (Table S3). This supports the replacement of EDTA with the more environmentally friendly chelating agents PDA and HEDP for removal of copper and biomass inherent inorganics. Additionally, it is noteworthy to point out that both potassium and sodium are completely extracted from the ties using only water, which is consistent with what has been reported in the literature. ${ }^{14}$ With all chelating agents, as well as with water, extraction efficiency significantly decreases with increasing thermal desorption severity. For example, 1.37 $\mathrm{mmol} / \mathrm{L}$ of copper is extracted using PDA from the nondesorbed sample, but only about $0.4 \mathrm{mmol} / \mathrm{L}$ is leached from the sample desorbed at $300{ }^{\circ} \mathrm{C}$ prior to extraction (Table S4). This demonstrates that as the thermal desorption temperature used for NA removal increases, inorganics become harder to remove from the ties. Percent removal of calcium decreases by $67.3,56.7,40.2$, and $17.3 \%$ with water, EDTA, PDA, and HEDP, respectively, from the untreated sample to the sample desorbed at $300{ }^{\circ} \mathrm{C}$ for $45 \mathrm{~min}$ (Table S3). This same trend is present for all inorganics quantified. Therefore, a trade-off between NA recovery and inorganic removal must also be taken into consideration when determining optimal conditions for $\mathrm{CN}$ removal from the used railroad ties.

The cause of this decrease in extraction efficiency with increasing desorption temperature could be due to several possible reasons. It has been demonstrated that thermal 


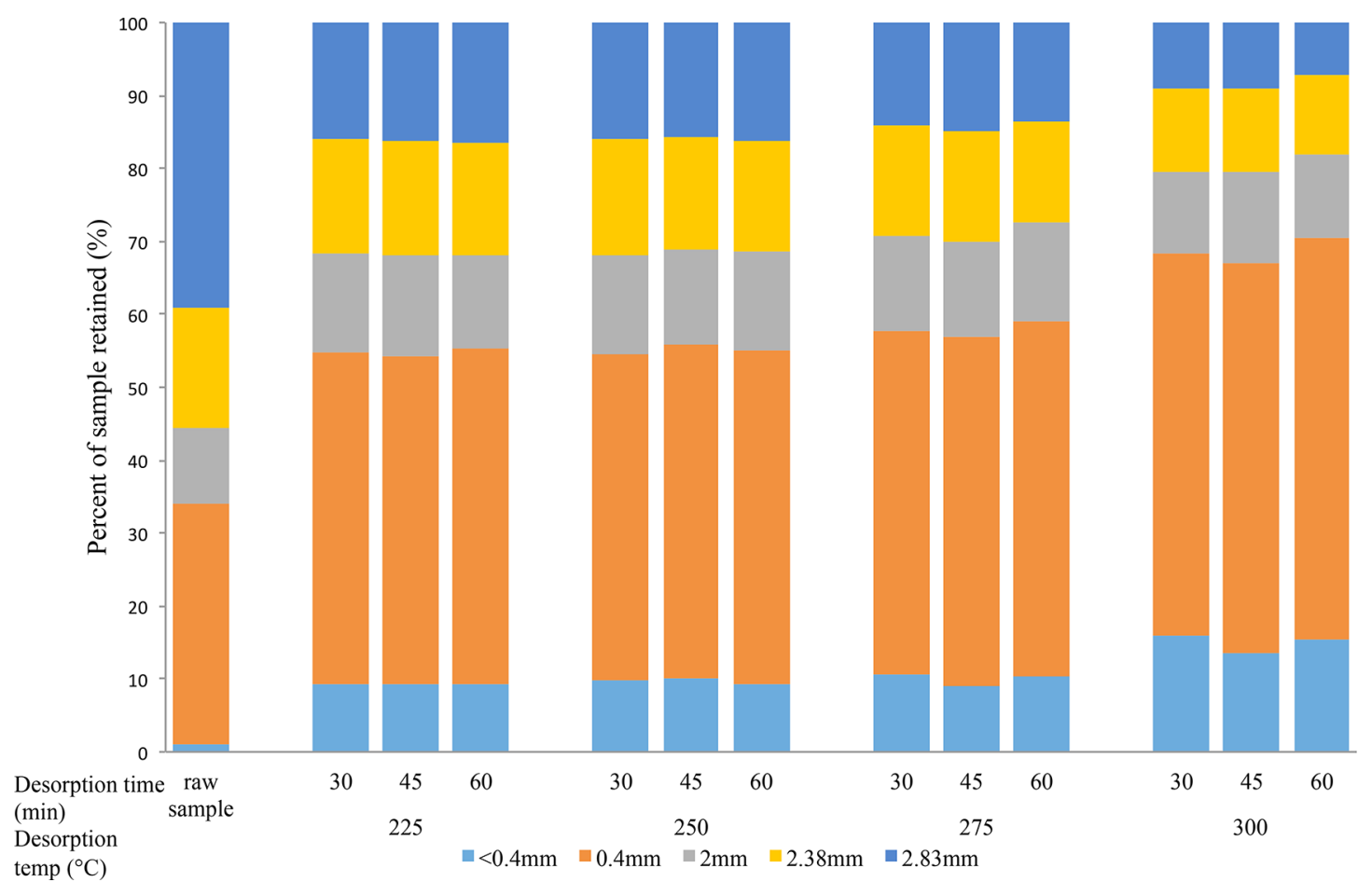

Figure 5. Particle size distribution of railroad ties after thermal treatment at varied temperatures and retention times.

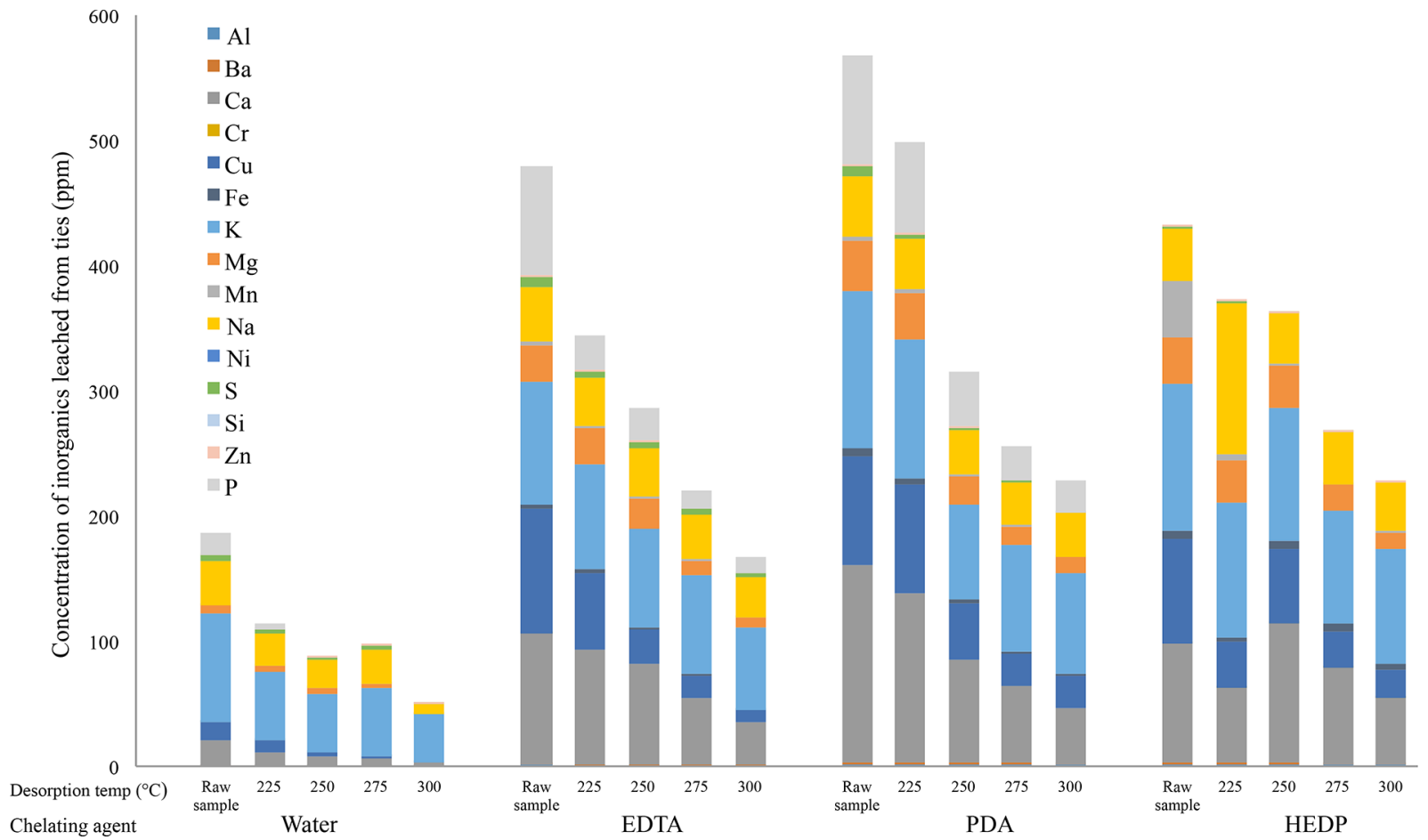

Figure 6. Inorganic composition of railroad ties extracted with EDTA, HEDP, PDA, or water after thermal desorption.

treatment can lead to oxidation of the metals; ${ }^{23,24,40}$ for example, converting copper to copper oxide. These oxides are inert and insoluble, thus reducing the amount of inorganics able to be extracted from the ties. ${ }^{24}$ While torrefaction decreases particle size and increases surface area, this treatment is also known to cause woody biomass to become more hydrophobic, ${ }^{11,25}$ which could be another cause of the reduction in extraction efficiency. A more hydrophobic wood structure would be much harder to penetrate by the chelating agents.
Without access into the wood structure, fewer inorganics would be accessible and removed from the ties. Only those on the surface would be extracted.

The ash content of the thermally treated ties steadily rises with an increase in thermal desorption temperature for all chelating agents tested but drops significantly after chelation for all samples except those extracted with HEDP (Figure 7). Samples extracted using HEDP have ash content significantly higher than that of the others, which can be attributed to the 


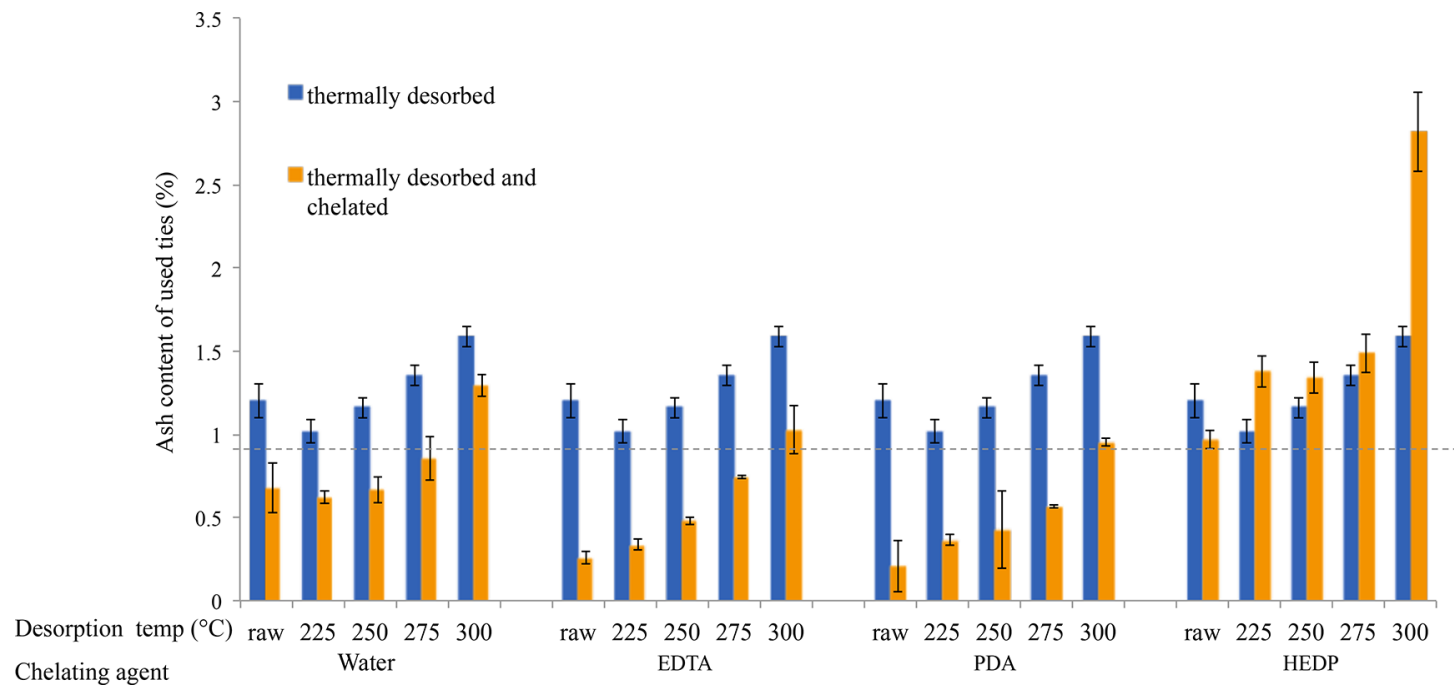

Figure 7. Effect of thermal desorption and chelation on ash content of copper naphthenate-treated ties.

introduction of additional phosphorus from the HEDP itself. The other chelating agents are composed of only carbon, hydrogen, oxygen, and nitrogen, while HEDP includes phosphorus. No washing of the wood was done after extraction to prevent additional water use that would increase cost and energy associated with implementing this process at an industrial scale; therefore, some of the HEDP and other chelating agents could remain in the solid fraction.

For thermochemical conversion, an ash content below $0.9 \%$ is desirable with an even smaller content preferable. ${ }^{41}$ The dashed line in Figure 7 represents this threshold. Thermal treatment of the ties between 250 and $275{ }^{\circ} \mathrm{C}$ followed by extraction with EDTA, PDA, or water result in biomass with an ash content lower than this desired limit with PDA extracted samples having the lowest ash content of the three (0.4-0.6\%) (Figure 7).

Therefore, the conditions suggested for optimum preservative removal are a temperature between 250 and $275{ }^{\circ} \mathrm{C}$ and a residence time of $45 \mathrm{~min}$, followed by inorganic extraction with the chelating agent PDA. This determination takes into consideration a trade-off between upgrading the ties for future thermochemical conversion, preservative removal, and inorganic extraction. Combining the use of thermal desorption with PDA extraction can support the recovery of $\mathrm{CN}$ components from used railroad ties and generate a high-quality biomass for thermochemical conversion processes, thereby reducing the landfilling of end-of-life ties by improving their value as a fuel source with this process. The value inherent in the carrier oil, $\mathrm{NA}$, and copper recovered from rail ties after their primary service make treated wood reuse or disposal both cleaner and more commercially viable. Applying this process to treat used ties on a larger scale would provide a secondary use for this renewable fuel source while also minimizing the negative environmental impact from landfill disposal of this biomass. This extraction method using the biodegradable chelating agent PDA can also be further applied beyond $\mathrm{CN}$-treated railroad ties for the lowering of ash content from other types of biomass, which is advantageous for bioenergy producers. This application is being investigated as a follow-up to this study.

\section{ASSOCIATED CONTENT}

S Supporting Information

The Supporting Information is available free of charge on the ACS Publications website at DOI: 10.1021/acssuschemeng.7b02760.

Figure S1, the experimental setup for thermal desorption with the bench-scale fixed bed reactor; Figure S2, resulting pyrogram from $\mathrm{GC} / \mathrm{MS}$ of $0.8 \%$ pure liquid copper naphthenate at $500{ }^{\circ} \mathrm{C}$; Table S1, quantification of inorganics leached from ground ties thermally desorbed for $45 \mathrm{~min}$ at $225,250,275$, or $300{ }^{\circ} \mathrm{C}$ and then extracted with EDTA, PDA, HEDP, and water determined using ICP-OES; Table S2, ash content of $\mathrm{CN}$-treated ties after thermal desorption and subsequent chelation using the same thermal treatment conditions as in Table S1; Table S3, percent removal of inorganics extracted from thermally desorbed ties after chelation with water, EDTA, PDA, and HEDP determined using ICP-OES; Table S4, inorganics extracted from thermally treated ties using EDTA, PDA, HEDP, and water determined using ICP-OES (PDF)

\section{AUTHOR INFORMATION}

\section{Corresponding Author}

*E-mail: nlabbe@utk.edu.

ORCID 우

Pyoungchung Kim: 0000-0001-6270-0473

Stephen C. Chmely: 0000-0002-2637-9974

Yagya N. Regmi: 0000-0001-6588-7683

Nourredine Abdoulmoumine: 0000-0001-6586-5919

Nicole Labbé: 0000-0002-2117-4259

Notes

The authors declare no competing financial interest.

\section{ACKNOWLEDGMENTS}

This work was supported by the IBSS Partnership which is funded by Agriculture and Food Research Initiative Competitive Grant from the USDA National Institute of Food and Agriculture (Grant 2011-68005-30410), the 2014-2015 AgResearch Innovation grant (the University of Tennessee Institute 
of Agriculture), and the USDA Agriculture and Food Research Initiative (AFRI, Grant 2015-6021-24121).

\section{REFERENCES}

(1) Freeman, M. H. Copper Naphthenate: An Effective Wood Pole and Crossarm Preservative. First Southeastern Pole Conference 1992, 68-77.

(2) Vlosky, R. Statistical Overview of the U.S. Wood Preserving Industry: 2007. Louisiana Forest Products Development Center 2009, 1.

(3) AWPA. Use Category System: User Specification for Treated Wood. Preservative Retention Specifications: Crossties and Switchties 2010, $U 1-10,1$.

(4) Commercial and Industrial Solid Waste Incineration Units: Reconsideration and Final Amendments; Non-Hazardous Secondary Materials that are Solid Waste; Final Rule. 2013; Vol. 78, https:// www.federalregister.gov/documents/2013/02/07/2012-31632/ commerical-and-industrial-solid-waste-incineration-unitsreconsideration-and-final-amendments (accessed October 2017).

(5) Smith, S. T. 2014 Railroad Ties Survey Report. Helena, M. T., Ed., RTA, AAR, and ASLRRA: 2015.

(6) Kim, P.; Lloyd, J.; Kim, J. W.; Abdoulmoumine, N.; Labbé, N. Recovery of creosote from used railroad ties by thermal desorption. Energy 2016, 111, 226-236.

(7) Kim, P.; Lloyd, J.; Kim, J. W.; Labbé, N. Thermal desorption of creosote remaining in used railroad ties: Investigation by TGA (thermogravimetric analysis) and Py-GC/MS (pyrolysis-gas chromatography/mass spectrometry). Energy 2016, 96, 294-302.

(8) Prins, M. J.; Ptasinski, K. J.; Janssen, F. J. J. G. More efficient biomass gasification via torrefaction. Energy 2006, 31 (15), 34583470.

(9) Prins, M. J.; Ptasinski, K. J.; Janssen, F. J. J. G. Torrefaction of wood. J. Anal. Appl. Pyrolysis 2006, 77 (1), 28-34.

(10) Wannapeera, J.; Fungtammasan, B.; Worasuwannarak, N. Effects of temperature and holding time during torrefaction on the pyrolysis behaviors of woody biomass. J. Anal. Appl. Pyrolysis 2011, 92 (1), 99105.

(11) Medic, D.; Darr, M.; Shah, A.; Potter, B.; Zimmerman, J. Effects of torrefaction process parameters on biomass feedstock upgrading. Fuel 2012, 91 (1), 147-154.

(12) Liu, W. J.; Tian, K.; Jiang, H.; Zhang, X. S.; Ding, H. S.; Yu, H. Q. Selectively improving the bio-oil quality by catalytic fast pyrolysis of heavy-metal-polluted biomass: take copper $(\mathrm{Cu})$ as an example. Environ. Sci. Technol. 2012, 46 (14), 7849-56.

(13) Yuan, H.; Xing, S.; Huhetaoli, H.; Lu, T.; Chen, Y. Influences of copper on the pyrolysis process of demineralized wood dust through thermogravimetric and $\mathrm{Py}-\mathrm{GC} / \mathrm{MS}$ analysis. J. Anal. Appl. Pyrolysis 2015, 112, 325-332.

(14) Edmunds, C. W.; Hamilton, C.; Kim, K.; Chmely, S. C.; Labbé, $\mathrm{N}$. Using a chelating agent to generate low ash bioenergy feedstock. Biomass Bioenergy 2017, 96, 12-18.

(15) Martins, J. G.; Neto, I. F.; Pinto, I. S.; Soares, E. V.; Barros, M. T.; Soares, H. M. Alternative chelating agents: evaluation of the ready biodegradability and complexation properties. J. Environ. Sci. Health, Part A: Toxic/Hazard. Subst. Environ. Eng. 2014, 49 (3), 344-54.

(16) Chang, F. C.; Wang, Y. N.; Chen, P. J.; Ko, C. H. Factors affecting chelating extraction of $\mathrm{Cr}, \mathrm{Cu}$, and As from CCA-treated wood. J. Environ. Manage. 2013, 122, 42-6.

(17) Ko, C. H.; Chen, P. J.; Chen, S. H.; Chang, F. C.; Lin, F. C.; Chen, K. K. Extraction of chromium, copper, and arsenic from CCAtreated wood using biodegradable chelating agents. Bioresour. Technol. 2010, 101 (5), 1528-31.

(18) Nowack, B. Environmental Chemistry of Aminopolycarboxylate Chelating Agents. Environ. Sci. Technol. 2002, 36 (19), 4009.

(19) Communities, C. o. t. E. Report from the Commision to the Council and the European Parliament: Pursuant to Article 16 of Regulation (EC) No 648/2004 of the European Parliament and of the Council of 31 March 2004 on detergents, concerning the use of phosphates; Brussels, 2007.
(20) Macauley, E.; Hong, A. Chelation extraction of lead from soil using pyridine-2,6-dicarboxylic acid. J. Hazard. Mater. 1995, 40, 257270.

(21) Pinto, I. S.; Neto, I. F.; Soares, H. M. Biodegradable chelating agents for industrial, domestic, and agricultural applications-a review. Environ. Sci. Pollut. Res. 2014, 21 (20), 11893-906.

(22) Deluchat, V.; Bollinger, J. C.; Serpaud, B.; Caullet, C. Divalent cations speciation with three phosphonate ligands in the $\mathrm{pH}$-range of natural waters. Talanta 1997, 44, 897-907.

(23) Barnes, H. M.; Kamdem, D. P.; Freeman, M. H. Copper Naphthenate-Treated Southern Pine Pole Stubs in Field ExposureChemical Characterization of Full Size Pole Stubs 12 Years After Treatment. In The International Research Group on Wood Preservation; Forest \& Wildlife Research Center, Mississippi State University: Kona, HI, 2000.

(24) Granholm, K.; Harju, L.; Ivaska, A. Desorption of Metal Ions from Kraft Pulps. Part 1. Chelation of Hardwood and Softwood Kraft Pulp with EDTA. Bioresour. 2010, 5 (1), 206-226.

(25) Van der Stelt, M. J. C.; Gerhauser, H.; Kiel, J. H. A.; Ptasinski, K. J. Biomass upgrading by torrefaction for the production of biofuels: A review. Biomass Bioenergy 2011, 10, 1.

(26) Felfli, F. F.; Luengo, C. A.; Suarez, J. A.; Beaton, P. A. Wood briquette torrefaction. Energy Sustainable Dev. 2005, No. 3, 19.

(27) Hong, A. P.; Chen, T. C. Chelating Extraction and Recovery of Cadmium from Soil Using Pyridine-2,6-Dicarboxylic Acid. Water, Air, Soil Pollut. 1996, 86, 335-346.

(28) Tandy, S.; Bossart, K.; Mueller, R.; Ritschel, J.; Hauser, L.; Schulin, R.; Nowack, B. Extraction of Heavy Metals from Soils Using Biodegradable Chelating Agents. Environ. Sci. Technol. 2004, 38, 937944.

(29) AWPA. Standards for Solvents and Formulations for Organic Preservative Systems; Washington, D.C., 1991; Vol. P9-91.

(30) AWPA. AWPA Book of Standards; AWPA: Birmingham, AL, 2016.

(31) Core, H. A.; Cote, W. A.; Day, A. C. Wood Structure and Identification, 1st ed.; Syracuse University Press: Syracuse, NY, 1976.

(32) Gucho, E.; Shahzad, K.; Bramer, E.; Akhtar, N.; Brem, G. Experimental Study on Dry Torrefaction of Beech Wood and Miscanthus. Energies 2015, 8 (5), 3903-3923.

(33) Chen, W. H.; Hsu, H. C.; Lu, K. M.; Lee, W. J.; Lin, T. C. Thermal pretreatment of wood (Lauan) block by torrefaction and its influence on the properties of the biomass. Energy 2011, 36 (5), 3012-3021.

(34) Apaydin-Varol, E.; Pütün, E.; Pütün, A. E. Slow pyrolysis of pistachio shell. Fuel 2007, 86 (12-13), 1892-1899.

(35) CAMEO Chemicals. In Chemical Datasheet: Naphthenic Acid; NOAA National Ocean Service Office of Response and Restoration: Silver Spring, Maryland, 2006.

(36) IPCS INCHEM. Diesel Fuel No. 2. http://www.inchem.org/ documents/icsc/icsc/eics1561.htm (accessed September 29, 2017).

(37) Arias, B.; Pevida, C.; Fermoso, J.; Plaza, M. G.; Rubiera, F.; Pis, $\mathrm{J}$. J. Influence of torrefaction on the grindability and reactivity of woody biomass. Fuel Process. Technol. 2008, 89 (2), 169-175.

(38) Kartal, S. N.; Kose, C. Remediation of CCA-C treated wood using chelating agents. Holz als Roh- und Werkstoff 2003, 61 (5), 382387.

(39) Janin, A.; Blais, J. F.; Mercier, G.; Drogui, P. Optimization of a chemical leaching process for decontamination of CCA-treated wood. J. Hazard. Mater. 2009, 169 (1-3), 136-45.

(40) Zyskowski, J.; Kamdem, D. P. Ultraviolet Spectrophotometry and Fourier Transform Infrared Spectroscopy Characterization of Copper Naphthenate. Wood and Fiber Sci. 1998, 11 (4), 441-446.

(41) Jones, S.; Meyer, P.; Snowden-Swan, L.; Padmaperuma, A.; Tan, E.; Dutta, A.; Jacobson, J.; Cafferty, K. Process design and economics for the conversion of lignocellulosic biomass to hydrocarbon fuels. USDOE 2013, 1 DOI: 10.2172/1126275. 